\title{
Credit Management and Bad Debt In Nigeria Commercial Banks -Implication For development
}

\author{
Agu, Osmond Chigozie ${ }^{1}$, Basil Chuka Okoli \\ Department Of Economics And Development Studies, Federal University, Oye-Ekiti
}

\begin{abstract}
This paper examines the causes of bad and doubtful debt in Nigeria commercial banks. It presents a framework to $x$-ray the risk and to validate the checks and balances to prevent or rather reduce the risk. The study uses both primary and secondary tools for data collection to determine causes of bad debts. Analysis of Variance (ANOVA) and autoregressive model were applied to validate the result spanning the period 1993 to 2011. Lending is one of the major functions of banks though the most risky. Yet any bank that wants to remain in business must lend. Due to the fact that bank's primary function is to act as intermediary between savers and borrowers, the barometer for measuring their earnings is interest from lending. Lending is a risk. Granting of credit is risk that can be viewed as the most important risk which Nigerian banks face bearing in mind the staggering size of their non-performing assets. Credit risk therefore is the risk which could occasion a loss for a bank due to a default by a customer in meeting its obligation. It is observed that incessant increase in interest rate is a strong and statistically important factor that causes bad debt in Nigeria commercial banks. Banks Management should establish sound lending policies, adequate credit administration procedure and an effective and efficient machinery to monitor lending function with established guidelines, reduce interest rates on lending. They should study the character and financial statement of the borrower before granting them loans.

Keywords: Bad debts, Customer's default, Credit risk, borrowers, nonperforming assets.
\end{abstract}

\section{Introduction}

In June 2012, the former Finance Minister, Anthony Ani, predicted that "the merged banks will eventually die" (Daily Sun, June 18, 2012). There have been debates about the banking industry and its rising and falling status, mergers and acquisitions, recapitalization and nationalization of banks, failed banks tribunal and so on since early 1980s. The underpinning was a lasting solution to the crisis that seems to engulf the banking industry.

Moreover, the banking industry has been known for its intermediation role in providing financial assistance (credit) needed in the economy. This role is normally carried out in many ways, for example, granting of loans and advances to customers, which constitute the major part of bank lending. Apart from loans and advances, there are other forms of banking or bank credits or bonds issued by banks for and on behalf of customers.

Banks are merely custodians of the money they lend; hence interest must be paid to depositors and dividends to the investors. Credit management can be seen as an integral part of lending and as such in its absence, good loans can turn bad. It is expedient to note that the importance of credit management cannot be over-emphasized and good credit management requires the establishment of adherence to and of sound and efficient credit policies of government. For banks to be successful, their corporate credit appraisal, disbursement, adequate monitoring and repayment must be assured. But experiences over the years have shown that inadequate credit analysis and sound judgment of loans application have resulted in unperforming loans. Provision of credits, which are in the form of loans and advances, are the total amount of money a given bank lends out to its customers at any given period of time. The bank usually charges the borrower interest for using its money. These loans and advances usually have maturity period.

In providing credits for business ventures, banks should as a matter of importance take all necessary steps to ensure that advances are granted to those customers who can and will make judicious use of loans so that repayment will not become a problem. Therefore credits must be made to people who are capable of utilizing it well and repaying the loan at its maturity. The place of loans and advances in the affairs of banks can be explained by referring to the fact that "loans and advances are the largest single item in the assets structures of Nigeria commercial Banks (Ani 2012)." It also constitutes the main source of the operating income of banks and also the most profitable assets for the employment of banks funds (Nwankwo 1980).

\section{Statement Of The Problem}

One of the ways to totally avoid bad debts is to refuse to lend money at all. If banks should then refuse to lend at all, then issue of profitability is cancelled and hence the main purpose of carrying on a business, 
which is to maximize profit, is then defeated. Credit must be adequately managed so that banks could remain in business and prudent lending could do this.

The provision for bad and doubtful debts rises steadily in banks annual reports which send bad signals to the investors within the economy. The cases of failed banks in the economy over the years have made the investors lose confidence in the banks. Hence, the existing evidence in Nigeria, points to a decline or stagnation of private investment during the immediate past reform years. The industries usually make short term planning as opposed to long term planning which tends to hamper their forecast and projection into the future activities and earnings. The success of any programme in bringing about a sustainable recovery in economic activity in an economy depends crucially on the behavior of investment in the aftermath of the reform process. In Nigeria, many reform programmes have been undertaken in the banking industry with little or no impact on the investment behaviour. The behaviour of private investment has been identified as a factor for assessing the reform outcome. The existing evidence in Nigeria, points to a decline or stagnation of private investment during the immediate past reform years (World Bank 1988, Harriggen and Mosley 1991, Green Way and Morrissey 1992; Gunning; 1994; Coller 1995, dehn, 2000; Lomi and Sisay,2001).

\subsection{Objective Of The Study}

The major objective of this study is to determine the major causes of bad and doubtful debts in Nigeria Commercial Banks. The specific objectives are:

i. To investigate the causes of bad and doubtful debts in Nigeria Commercial Banks

ii. To examine the effects of bad and doubtful debts in banks profitability, investors, the public and the economy.

\subsection{Literature Review}

The already existing literature on this subject matter deal substantially on the banking operations, performance and management.

\subsection{Factors Responsible For Customer's Default}

According to Onwudiegwu (2001), the concept of default is less obvious than it first seems, for it could result from non - or delayed payment of interest and or principal for a given period. One or a combination of the following factors could contribute immensely to default especially in a depressed economy. The more one borrows; the more one would want to borrow consequently. The volume of the loan would increase which decreases the ability to repay as opposed to the willingness to repay. The ability to repay increases with increased net income although that does not say anything about the willingness to repay. One would expect borrowers with high net income to have low debt/equity ratio, the lower the debt/equity ratio, the higher the ability to repay. The effect of high net income and low debt/equity ratio is a precaution for borrowers to build up valuable assets. Onwudiegwu (2001) equally posited that, as the value of the collateral increases, the default rate is expected to decline. Where there is income variance as a result of economic or natural circumstance, credit service ability per individual borrower decreases and hence default could increase. Such income variances are common in agricultural and manufacturing sectors. The higher the interest rate, the more the outstanding balance the borrowers have to pay considering the principal. Rate of inflation has link with the real interest to be paid by the borrowers. If inflation is higher than the interest rate, it will mean that the lending bank would be paying borrowers to take its loans. The close monitoring of borrowers to ensure a loan is not diverted to unproductive use, though costly, has a lot of bearing on ability of the borrower to repay. The effort is put in ensuring utilization of a facility, the less chance of default.

\subsection{Interest Rate and Private Investment in Nigeria}

User's cost of capital is an indispensable factor in any investment decision of the private sector. Any increment in user's cost (interest rate) of capital will bring about a decline in investment. Interest rate can have a substantial effect on the rate and pattern of repayment of debt and of economic growth by influencing the volume of productivity, disposition of saving as well as volume and productivity of investment. The Keynesian investment theory and the Mckinnon-shaw (1973) savings and investment hypothesis constitute the theoretical basis for the use of interest rate policy in stimulation of the economy via investment. The Keynesian theory implies that low interest rate, as a component of cost of funds, encourages borrowing for investment. Some empirical findings are inconsistent with the fact. (Green and Villanueva 1991, negative relationship between interest rate and investment, studies by others (Serven and Solimano 1993, Van wijubergen 1985) have shown that in repressed financial markets. Credit policy affects investment in a distorted manner. Skully (1997) also in his study on Fiji and other countries in the region stressed that the availability of finance has constraint for private investment in Fiji. 


\subsection{Securities For Bank Lending}

Securities for bank lending are property pledged as collaterals for loans by borrowers. Securities are the general name for stocks, mortgages, bonds, and certificates showing ownership of property. From the foregoing, the preview of securities for bank lending shall be limited to such properties held as securities by banks in Nigeria. Shegolar and Thomas (1999), Mandel (2000)

From the diagnosis of the Nigerian Banking system, some of the securities held by banks before any lending is made to any individual, corporation or government and those securities often demanded by banks for loans and advances in the country have been shown to be quite unsatisfactory. One of such is the requirement of bank that prospective borrower should pledge any real estate holding for loans given to them. Such estate includes heavy plants and machinery, landed properties and other physical assets. Real estate properties must be immovable properties. The advantage it has to the bank is that due to the fact that it is stationary, the banks lay confidence on it to recover its debts in case of default. This category of security constitutes a major singular security in Nigeria banking industry) Mandel (2000) According to Olayinka (1999) other securities pledged by customers wishing to borrow from the bank is their money in either saving, current or time deposits, especially if the account has a regular cash flow usually from any salaries or wages or even other private sources.

\subsection{Criteria For Lending On Bankable Project}

According to Olayinka (1999) banks generally provide avenue for savings to those who have surplus funds and the bulk of such funds are lent out to needy customers in form of loans and overdrafts. Thus, when a commercial bank is approached for loans, special guidelines have to be followed. He went further to say that such bank has its general principles, for example, some banks use the PAPERS criteria and 5C'S of credit lending:-

$\begin{array}{lll}\mathrm{P} & - & \text { Person } \\ \mathrm{A} & - & \text { Amount } \\ \mathrm{P} & - & \text { Purpose } \\ \mathrm{E} & - & \text { Equity } \\ \mathrm{R} & - & \text { Repayment } \\ \mathrm{S} & - & \text { Security. }\end{array}$

5cs are character, capacity, capital, collateral and condition (Olayinka 1999)

The customer is expected to be able to determine fairly accurately how much finance he requires. He should therefore submit a cash budget. The capital resource will also have to be determined to ascertain whether the bank is being asked to lend too much in comparison with the resources.

\subsection{OBSTACLES TOWARD EFFECTIVE PERFORMANCE}

As should be expected in most business enterprises in developing economies the banking industry has certain factors that are militating against the effective performance of their lending function. Most of the people operating various businesses in Nigeria are illiterates. They do not easily understand nor do they appreciate reasons a lot of difficulties are encountered if loans are mismanaged. Explaining to such business men and women ways and means of improving their account with the bank before asking for loan is usually a mere waste of time. They would prefer to offer kickbacks than to understand the simple operation of the system. (Okoh 1997). The credit departments of some banks do not have the required level of man power and the will needed to perform difficult and technical transactions involved in lending.

\subsection{Bank Recapitalization And Consolidation}

The banking sector has a long way to go, in playing its expected role in the development and growth of the economy. To activate the potentials of banks in the economy, there is the need to employ certain pro-active measures Egwuatu(2004). Prior to the year 2004, the bank's capital base was about two billion naira. A family can therefore contribute that sum and register / own a bank and begin to gather deposits from the public. Managing the fund becomes a problem because there may not be liquid enough to cater for the financial needs of the public. This leads to frequent bank failure. The banks were not giving long term loans because they would want to get back their money on time to avoid the problem of bad and doubtful payment.

Their aim therefore, is to shore up the financial base of the banks in the country beyond fragile level. The fragmented nature of the banking industry could a real obstacle to development and growth of the economy. The fragmented nature of the banking industry has been partly attributed to the high interest rate regime in the country. The hope of lower interest rate will have to come from a rising stock of long term funds in the system. 
Edozie(2005) pointed out that, due to the frequency of bank failure in Nigeria the CBN decided to increase the capital base of the banks to twenty five billion naira to make the banks stronger financially and to be more liquid. The banks that could not make it, merged with two or more banks to recapitalize. Some banks acquired one or more banks to recapitalize so as to be stronger financially.

\section{Methodology, Materials And Sources Of Data}

This section discusses the methodology and theoretical significance of the study. Issues relating to the choice of research design and strategies, model specification, data requirements and sources, the nature and scope of data collected, the data processing technique and the theoretical significance of parameter estimate are discussed.

\subsection{Research Design and Strategies}

The study approach and style of this research are both empirical and analytical in nature. It employs quarterly time series data spanning the period 1993 to 2011 and Regression analyses. To do this successfully, the above methods were employed so as to identify the nature and causes of bad and doubtful debts.

The study uses experimental research design approach for the data analysis. The approach combines theoretical consideration (a prior criteria) with the empirical observation and extracts maximum information from the available data.

For the purpose of collection of relevant data on this research study, both primary(direct oral Interviews, questionnaires) and secondary data(banks annual statements, Journals, Magazines, Newspapers, periodicals, CBN brief series, bullion magazines etc. were used.

\subsection{Empirical Model (Vector Autoregressive(VAR)Model)}

VAR model is the best model for investigating differences in transmission among variables because they provide information on impulse responses(Adebiyi and Adeyemi 2006) they serve as a flexibble approximation reduced form of any wide variety of simultaneous structural model(Adebiyi,2006). VAR model of two endogenous variables with only one lag in each variable with the constants suppressed can be written as:

$$
\begin{aligned}
& X_{i t}=a_{11} X_{1 t-1}+a_{12} X_{2 t-1}+\ddot{E}_{1 t} \\
& X_{2 t}=a_{21} X_{1 t-1}+a_{22} X_{2 t-1}+\ddot{E}_{2 t}
\end{aligned}
$$

Where $\mathrm{X}_{1 \mathrm{t}}$ and $\mathrm{X}_{2 \mathrm{t}}$ represent the relationship between the interest rate and the bank profitability (liquidity). $\ddot{E}_{1 \mathrm{t}}$ and $\ddot{\mathrm{E}}_{2 \mathrm{t}}$ are error terms, which are 'white noise'.

$\mathrm{n}$ practice, there would be more than two endogenous variables and often more than one lag. In this case with $\mathrm{k}$ endogenous variables and P lags, we can write the VAR model in matrix notation as:

$$
X_{t}=A_{1} X_{t-1}+\ldots \ldots \ldots \ldots A_{p} X_{t-p}+\ddot{E}_{t}
$$

Where $\mathrm{X}_{\mathrm{t}}$ are its lag values, an $\ddot{\mathrm{E}}_{\mathrm{t}}$ are $\mathrm{k} \times \mathrm{k}$ matrices of constant to be estimated Using two equation system (1), we can write the system in terms of lag operator $L$ as: 


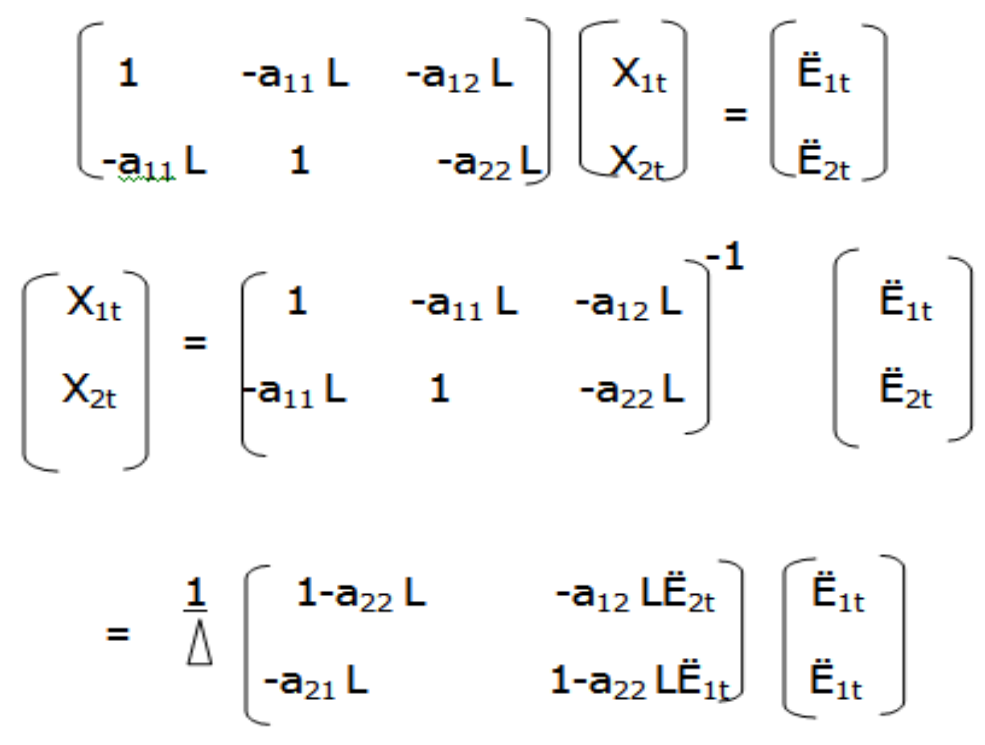

Where

$\triangle=\left(1-\mathrm{a}_{11} \mathrm{~L}\right)\left(1-\mathrm{a}_{22} \mathrm{~L}\right)=1-\left(\mathrm{a}_{11}+\mathrm{a}_{22}\right) \mathrm{L}+\left(\mathrm{a}_{11} \mathrm{a}_{22}-\mathrm{a}_{12} \mathrm{a}_{21}\right) \mathrm{L}^{2}=\left(1-\mathrm{H}_{1} \mathrm{~L}\right)\left(1-\mathrm{H}_{2} \mathrm{~L}\right)$

Where $\mathrm{H}_{1}$ and $\mathrm{H}_{2}$ are the roots of the equation and $\mathrm{H}_{2}-\left(\mathrm{a}_{11} \mathrm{H}+\mathrm{a}_{22} \mathrm{H}\right)+\left(\mathrm{a}_{11} \mathrm{a}_{22}-\mathrm{a}_{12} \mathrm{a}_{21}\right)=0$

The convergent expansion for $X_{1 t}$ and $X_{2 t}$ in terms of $\ddot{E}_{1 t}$ and $\ddot{E}_{2 t}$ is obtained when $H_{1} /$ and $H_{2} /$ are less than unity. Once the condition for stability is satisfied, $\mathrm{X}_{1 \mathrm{t}}$ and $\mathrm{X}_{2 \mathrm{t}}$ can be expressed as a function of the current and lagged values of $\ddot{E}_{1 \mathrm{t}}$ and $\ddot{\mathrm{E}}_{2 \mathrm{t}}$ which are referred to as the impulse response functions (Adebiyi and Adeyemi 2007). Impulse response functions show the current and lagged effects over time of change $\ddot{\mathrm{E}}_{1 \mathrm{t} \text { and }} \ddot{\mathrm{E}}_{2 \mathrm{t}}$ on $\mathrm{X}_{1 \mathrm{t}}$ and $\mathrm{X}_{2 \mathrm{t}}$.

Two results obtainable from VARs, which are useful for analyzing the transmission mechanism, are the impulse response functions and the forecast error variance decompositions. The impulse responses tell us how macro variables respond to shocks in the policy variables while the variance decompositions show the magnitude of the variation in the macro variables due to the policy variables. VAR models are routinely used to perform impulse response analysis, which allows us to measure the various period impacts of $Y_{t-1}$ on $Y_{1 t}$ and $Y_{2 t}$. Impulse response analysis requires a vector moving average (VMA) representation of a VAR. The VMA allows us to trace out the time path of the various shocks on the variables of the VAR system. To produce reliable VAR estimates and impulse response analysis, variables of the model are required to be stationary, that is, they should not have unit roots.

\subsection{Analysis of Variance}

\section{Presentation And Discussion Of Findings}

Since the focus of this study is to determine the cause of bad debt in Nigerian bank, it provides an empirical insight into the relationship between bank liquidity and interest rate using regression analysis.

Table 1 suggests that the null hypothesis of no co-integration between liquidity and interest rate can be rejected at $5 \%$ level. Given the strong evidence that the series are stationary and do co-integrate. It could be seen that 97.7\% positive response were of the opinion that increase in interest rate on loans (lending rate) and advances is a contributing factor to problem loans. While $2.3 \%$ negative responses agitated that increase in interest rate on loans does not contribute to problem loan and advances in Nigeria commercial banks.

Furthermore, TABLE 2, when regression is applied in testing the above hypothesis, suggests that the null hypothesis is rejected which implies that a high interest rate on loans and advances has bearing or is a contributing factor to increasing amount of bad and doubtful debts in Nigeria commercial banks.

The paper is therefore of the opinion that, this was the reason the central bank of Nigeria introduced interest rate policy and sartorial allocation of credits, which determines a fixed rate of interest to be charged by banks on some sectors of the economy. This is to monitor the rate of interest charged by banks in extending credits to its customers.

TABLE 1 Regression Results Coefficients(a)

\begin{tabular}{|l|l|l|l|l|l|l|l|l|}
\hline $\begin{array}{l}\text { Mode } \\
1\end{array}$ & & \multicolumn{2}{|l|}{$\begin{array}{l}\text { Unstandardized } \\
\text { Coefficients }\end{array}$} & $\begin{array}{l}\text { Standardized } \\
\text { Coefficients }\end{array}$ & $\mathrm{t}$ & \multicolumn{2}{l|}{$\begin{array}{l}\text { Sig. } \\
\text { for B Confidence Interval }\end{array}$} \\
\hline & & & $\begin{array}{l}\text { Std. } \\
\text { Error }\end{array}$ & Beta & & & $\begin{array}{l}\text { Lower } \\
\text { Bound }\end{array}$ & Upper Bound \\
\hline 1 & & B & .033 & & 31.549 & .000 & .9774 & 1.123 \\
& (Constant & 1.056 & .009 & -.123 & -1.068 & .289 & -.029 & .009 \\
\hline
\end{tabular}


TABLE 2 Regression results

\begin{tabular}{|l|l|l|l|l|}
\hline $\begin{array}{l}\text { Mod } \\
\text { el }\end{array}$ & R & $\begin{array}{l}\text { R } \\
\text { Square }\end{array}$ & $\begin{array}{l}\text { Adjuste } \\
\text { d R R } \\
\text { Square }\end{array}$ & $\begin{array}{l}\text { Std. of } \\
\text { the } \\
\text { Estimate }\end{array}$ \\
\hline 1 & $.123(\mathrm{a})$ & .015 & .002 & 1.978 \\
\hline
\end{tabular}

\begin{tabular}{|l|l|l|l|l|l|l|}
\hline Model & & $\begin{array}{l}\text { Sum of } \\
\text { Square } \\
\text { s }\end{array}$ & Df & $\begin{array}{l}\text { Mean } \\
\text { Square }\end{array}$ & F & Sig. \\
\hline $\begin{array}{l}\text { Regres } \\
\text { sion }\end{array}$ & $\begin{array}{l}4.461 \\
\text { Residu }\end{array}$ & $\begin{array}{l}289.48 \\
\text { al }\end{array}$ & 74 & 4.461 & 1.140 & .289 (a) \\
Total & 293.94 & 75 & & & \\
7 & 7.912 & & & \\
\hline
\end{tabular}

Source: Author's computation from questionnaire

\subsection{Vector Autoregressive Model Comprising interest rate and Liquidity(Profitability)}

To further verify the empirical findings, the study estimates an unrestricted vector autoregressive model in levels using four lags of each variable and including a constant. The VARs results varies across pattern (table 3) suggests that between 1993 to 1996(first quarter) the interest rate was negatively signed with the profitability(Liquidity). The same response goes between 2001 to 2004(third quarter) and 2005 to 2008(fourth quarter). We noticed a deviation in response of the borrowers between 1997 to 2000 (second quarter) which might be as a result of the reduction in interest rate. It corroborates the findings of (Mordi 2008). The VAR result in 2009 to 2011(fifth quarter) shows the same positive sign as the second quarter but the response of the borrowers to interest accruable and or repayment of the loan was not encouraging. This may not be unconnected to the fact that some "big wigs" in the banking sector collect kickbacks from the borrowers before loans are approved which make them lose the moral character and courage of pursuing the borrowers to repay the loan as at when due (Agu 2010).

It is equally worth noting that the period $1985-2008$ contain period of policy shift and structural breaks which the study has not reflected. For example, the period between 1985 - 1995 cover a regime of more flexible prices (interest rate and exchange rate) in Nigeria and hence, these variables are volatile. The period 1999 - 2004 was characterized by full deregulation, while $2004-2008$ was the period of banking and financial sector reforms.

The table and graphs below equally suggest that (looking at the ratio of loan \& advances to deposit, Bank balances with $\mathrm{CBN}$ and balances due to other banks), one can infer that the banks have a huge unperforming loan. The huge unperforming loan may not be unconnected to one of the reasons the CBN Governor recently fired some Managing Director of banks in Nigeria.

\begin{tabular}{|c|c|c|c|c|c|c|c|}
\hline intercept & & $\begin{array}{l}-1.8763 \\
(-2.311)\end{array}$ & $\begin{array}{l}2.0324 \\
(1.874)\end{array}$ & $\begin{array}{l}-1.7251 \\
(-2.634)\end{array}$ & $\begin{array}{l}-1.8623) \\
(-2.482)\end{array}$ & $\begin{array}{l}1.6013 \\
(2.653)\end{array}$ & $\begin{array}{l}-1.7211 \\
(-2.044)\end{array}$ \\
\hline \multirow[t]{7}{*}{ 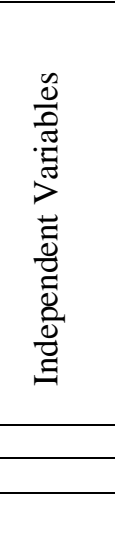 } & \begin{tabular}{l}
\multicolumn{2}{l}{ INTEREST RATE } \\
DEPOSIT \\
LOAN \\
ADVANCES \\
BALANCES \\
CBN WITH \\
BALANCES DUE \\
TO D \\
BANKS OTHER
\end{tabular} & $\begin{array}{l}-0.4241 \\
(-2.423)\end{array}$ & $\begin{array}{l}0.0221 \\
(0.546)\end{array}$ & $\begin{array}{l}-0.6192 \\
(-3.532)\end{array}$ & $\begin{array}{l}-0.3017 \\
(-0.0993)\end{array}$ & $\begin{array}{l}-0.2221 \\
(-1.936)\end{array}$ & $\begin{array}{l}-0.4015 \\
(-2.053) \\
0.0121 \\
(0.352) \\
-0.5328 \\
(-2.764) \\
-0.1017 \\
(-1.063) \\
-0.2132 \\
(-1.782)\end{array}$ \\
\hline & $\mathrm{F}$ (stat) & 0.4623 & 0.4012 & 0.5432 & 0.4553 & 0.3362 & 0.564 \\
\hline & $\mathrm{R}$ & 0.1256 & 0.3543 & 0.756 & 0.5463 & 0.5463 & 0.765 \\
\hline & SE & 0.987 & 0.876 & 0.987 & 0.765 & 0.564 & 0.576 \\
\hline & $\mathrm{T}$ (stat) & 31.4 & 27.6 .6 & 44.5 & 34.6 & 536.7 & 36.8 \\
\hline & $\mathrm{R}^{2}$ & 0.59 & 0.61 & 0.74 & 0.60 & 0.63 & 0.68 \\
\hline & & $\begin{array}{l}\text { 1stqtr } \\
1993-1996\end{array}$ & $\begin{array}{l}\text { 2ndqtr } \\
1997-2000\end{array}$ & $\begin{array}{l}\text { 3rdqtr } \\
2001-2004\end{array}$ & $\begin{array}{l}\text { 4thqtr } \\
2005-2008\end{array}$ & $\begin{array}{l}\text { 5thqtr } \\
2009-2011\end{array}$ & \\
\hline
\end{tabular}

Source: Authors computation (from CBN Annual Reports and Statement of Accounts (Various Issues). 
z- statistic in brackets

Graphs showing the trend of Total Deposits and Total credit (1993- 2011)

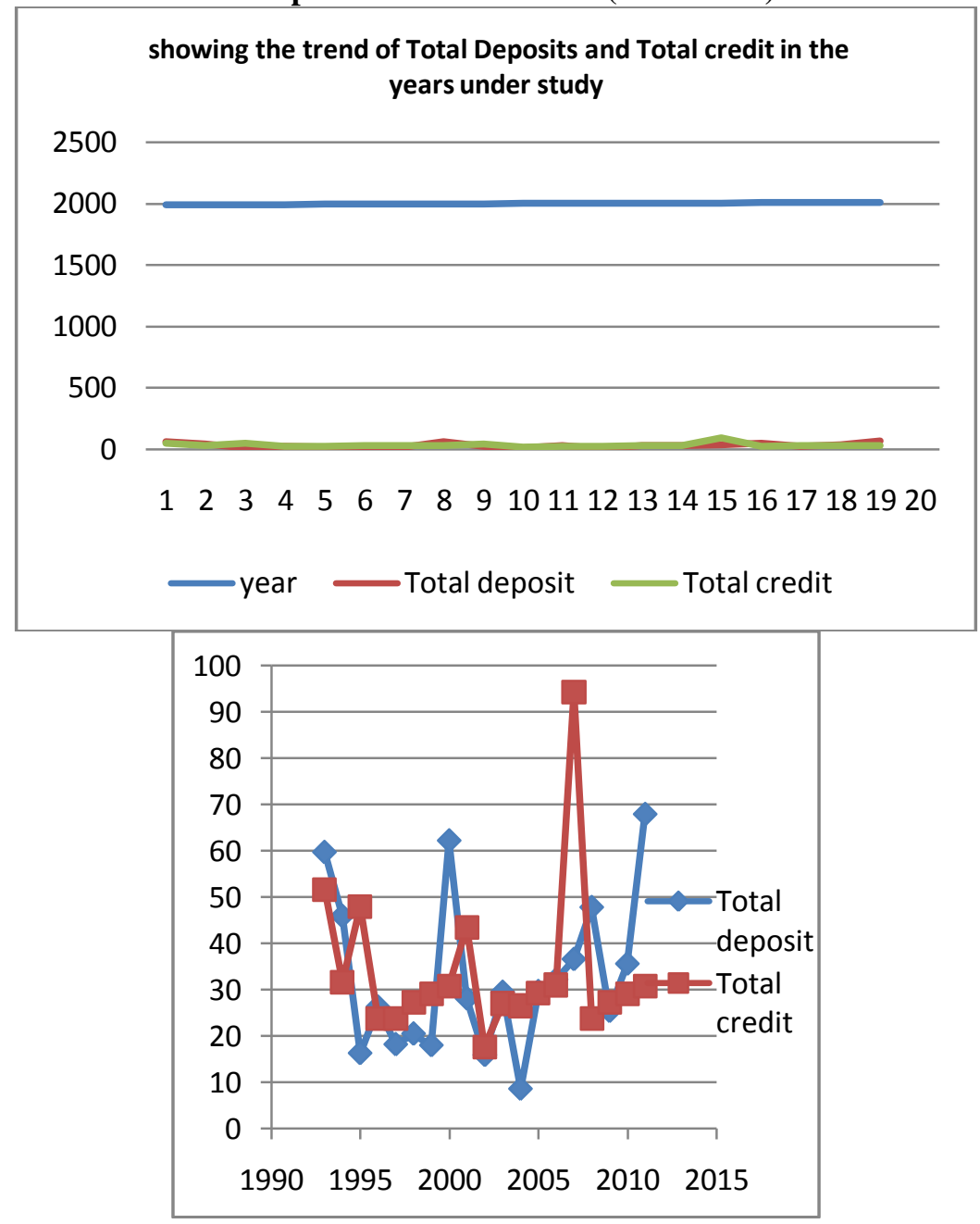

Table 4: Targets and outcomes of Key Monetary aggregates and Other Macro economics Variables(1993-

$\begin{array}{cccccc}\text { year } & \text { Total deposit } & \text { Total credit } & \text { GDP } & \text { Inflation rate } & \begin{array}{c}\text { Exchange } \\ \text { rate(N/\$) }\end{array} \\ 1993 & 59.7 & 51.6 & 2.7 & 61.3 & 22.05 \\ 1994 & 45.9 & 31.7 & 1.3 & 76.8 & 21.89 \\ 1995 & 16.3 & 48 & 2.2 & 51.6 & 70.36 \\ 1996 & 26.3 & 23.9 & 3.4 & 14.3 & 69.84 \\ 1997 & 18.2 & 23.9 & 3.2 & 10.2 & 71.75 \\ 1998 & 20.5 & 27.4 & 2.4 & 11.9 & 76.81 \\ 1999 & 18.0 & 29.2 & 2.7 & 0.2 & 92.34 \\ 2000 & 62.2 & 30.9 & 3.0 & 14.5 & 101.65 \\ 2001 & 28.1 & 43.5 & 3.8 & 16.5 & 111.9 \\ 2002 & 15.9 & 17.7 & 4.6 & 12.1 & 121.0 \\ 2003 & 29.5 & 27.1 & 9.6 & 23.8 & 129.4 \\ 2004 & 8.6 & 26.6 & 6.6 & 10 & 133.5 \\ 2005 & 29.66 & 29.3 & 6.5 & 11.6 & 132.1 \\ 2006 & 32.18 & 31.1 & 6 & 8.5 & 128.7 \\ 2007 & 36.6 & 94.3 & 6.4 & 6.6 & 146.5 \\ 2008 & 47.8 & 23.9 & 6.9 & 8.6 & 146.5 \\ 2009 & 25.4 & 27.4 & 6.7 & 7.6 & 153.4 \\ 2010 & 35.6 & 29.2 & 5.5 & 8.5 & 151.5 \\ 2011 & 67.9 & 30.9 & 5.9 & 7.5 & \end{array}$

SOURCE: Author's Standard Deviation computation from CBN Annual Report and Statement of Accounts(Various Issues) . N/\$ values are the real exchange rate for the periods under consideration 


\section{Summary Of Findings, Recommendations And Conclusion}

\subsection{SUMMARY OF FINDINGS}

The survey confirmed the increasing existence in the amount of bad and doubtful debts in Nigeria Commercial Banks of which the major causes are:-

i. Inadequate close monitoring of the borrowers to ensure proper utilization of fund (i.e on site visit to factory or project site).

ii. Incessant increase in interest rate (lending rate)

iii. Lack of adequate knowledge of the loan seeker

iv. Failure by Commercial Banks to give their loan immediate follow-up to avoid diversion.

v. Poor credit policy administration.

The summary also reveals inefficient credit management, which results in high bad debts portfolio, which is the principal cause that drives banks to their untimely grave. The effects of these bad debts as revealed by the survey were.

\section{$5.2 \quad$ Implications}

\subsubsection{Effects On Banks}

1. Bad debts destroy loan which are banks earning assets. They are the source of earning as well as the essential determinants of the liquidity and ultimate solvency of the bank. It is these earnings that translate into cash, which of course is the life and blood of any business. Eating them up therefore, amounts to slamming death certificates on banks.

2. Due to the fact that the higher the bad debts written off from the profit of the bank, the lower the net profit and, therefore, the amount available for distribution as dividends to shareholders and, in fact, the amount ploughed back into the business to enhance its future revenue earning capacity.

\subsubsection{Effects On The Society}

1. Since credits (loans and advances) are funds availed the deficit unit for investment purpose, the amount available for future credit is lowered. Because the loan is lost, it becomes impossible to re-cycle that particular fund (as demonstrated above), which may have enabled new projects, take off or existing ones expand.

2. Social services to communities by government are covered because lowered taxes result from reduced profits occasioned by bad debts.

\subsubsection{Effects On The Banking Public}

1. Loss of substantial portion of deposit

2. The banking culture is threatened due to lack of confidence in the financial system.

\subsubsection{Effects On Shareholders}

1. Reduction on the amount available for shareholders as dividends due to reduction on profits occasioned by bad debts.

2. Lose future earning because of stunted growth arising from paucity of reserve

\section{Recommendations}

The prescription for bad and doubtful debts in Nigeria Commercial Banks could be resolved through the following recommendations:-

i. Banks Management should establish sound lending policies, adequate credit administration procedure and an effective and efficient machinery to monitor lending function with established guidelines.

ii. Reduction of interest rates on lending.

iii. The character and financial statement of the borrower must be properly studied.

iv. The Central Bank of Nigeria should re-introduce interest rate regulation on banks.

v. Banks should be making public the names of bad and doubtful debtors (by compilation of bad debtors' black book in banks).

vi. For agricultural lending, the rate should be pegged; say 5\% while banks that extended such credits to farmers should be allowed to recoup their loss margin through fax rebate among other incentives.

vii. Giving business advisory services to customers and further extension of credit to alleviate a promising problem loans.

viii. Finally, the financial institutions should all together, set up credit bureau system which is a form of data bank where every bank will submit the names of its defaulting customers for references by others. This will equally frustrate multiple borrowing from banks for the same purpose by the dubious customers. 


\section{Concluding Remarks}

In conclusion, lending involves more risk than virtually any other banking activities. Not all loans should be granted. A profitable loan, which is not safe, should not be granted. The attitude of most borrowers towards loans and advance granted to them should not be ignored - as they regard such credit facilities as their own share of the national cake. Moreover, some fraudulent bank officials receive bribe before approving loans, some officials still bargain the percentage of the credit to be given to them before the approval is made. These eventually lead to poor appraisal of such facility and as well in danger of becoming a doubtful debt because such a bank officials will lack the moral justification to pursue and recover the loan. Furthermore, failure of banks to make use of trained, qualified and experienced personnel in their credit management is a problem that should be addressed

Management should therefore analyze the nature of risk carefully before extending credit.

Efficient and effective credit management remains a hidden treasure the exact value of which undiscerning boards may be unaware. Efficiency should be predicated on a high quality credit management and adherence to professional banking ethics.

It is however, gratifying that, to ensure compliance by enthroning deterrence, the CBN plans a Credit Risk Management Bureau to stem the activities of bad debtors. Credit Bureau (Alao 1996) is envisaged to provide information on bank debtors and their profit to enable banks take decisions on persons applying for loans. This is to arrest the ignoble activities of bad debtors and their accomplices who move from one bank to another leaving a trail of non-performing loans. This will enhance the compilation of "Bad Debtors Black Book" advocated by Sadiku (1993). If this book is introduced, people will be scared to have their names in that register.

\section{References}

[1]. Agu, O. C. (2010) Credit Management and Bad Debt in Nigeria Commercial Banks: MSc thesis submitted to the Dept. of Economics, Nnamdi Azikiwe University, Awka.

[2]. Adebiyi, M.A. and S.B. Adeyemi (2007) Inflation Targeting in Developing Economies: the case of Nigeria. Nova Science Publishers, Inc.

[3]. Adeniyi O. (2002), The Elements of Banking In Nigeria, Graham Burn Ltd. London

[4]. Adekaye T. (2005) Banking Methods and Practices Hosanna Publication Ltd, Enugu.

[5]. Adebiyi, M.A (2006) "Financial Sector reforms and Impact of Monetary Policy Shocks in Nigeria: Wageningen Academy Publishers, Manholt Publication Series Vol. 1

[6]. Ani A.(2012) “Abacha Didn’t Steal Money” Daily Sun, Monday June 18,2012

[7]. Anyawaokoro M. (1996), Banking Method And Processes Hossana Publication, Enugu

[8]. Ajayi B. (1999), "Excess Liquidity and Unplanned Inventory”. Business Times Thursday 4 Dec.1999.

[9]. Alao S. (1996) "Banks Scramble to Invest Idle Funds". Business Times Monday, May 121996.

[10]. Anaeto E. (1997), “Considerations for Loan Receivers”. Business Times. Monday 1 March 1997.

[11]. CBN(1997), CBN Monetary, Credit, Foreign Trade and Exchange Policy Guideline For 1997,Fical Year.

Circular 31.

[12]. Emekekwe P. (2000) Commercial Banking in Africa, Bureau Education Series, Kinshasha Zaire

[13]. Ewelike T. (1991) The Lending Considerations, The Nigeria Bankers. A paper presented at the seminar of Nigeria Economic Students Association (NESA) March1991.

[14]. Egwuatu (2004) "Banking Industry Recovery In Nigeria" The Vanguard, Wednesday, July 7, 2004

[15]. Edozie P. (2005) "Consolidation In Nigeria Banks" The Guardian, Thursday, 15 June 2005.

[16]. Furness R.B. (2005), Money and Banking, Prentice Hall Inc., New Jersey.

[17]. Greene, J. and D. Villanueva (1991). "Private Investment and Developing Countries: An Empirical Analysis", IMF Staff Papers, $38(1)$

[18]. Handerson M.J. (1998), Banking Operation, D.P. Publishers Ltd. London.

[19]. Hale R.H. (1983) Credit Analysis - A Complete Guide, Willey Interscience Publication

[20]. Kinnon, M. C. (1973) Money and Capital in Economic development Washington DC: The Brookings Institute.

[21]. Mandel S. (2000) Law Governing Banks and Their Customers, Willey Adison Ltd

[22]. Mathur I.(2000) Introduction To Financial Management, Macmillian Publishers Com. London

[23]. Mordi C.N.O (2008) Recent trend in Monetary Management, Nigeria Journal of Securities and Finance. Vol.14, number1.

[24]. Miller D.T. (2004) The Meaningful Interpretation Of Financial Statement. American Management Association, New York

[25]. Nwankwo G.O. (1999) The Nigeria Financial System Macmillian Ltd, London.

[26]. Orjih J.(1996), Element Of Banking, Rock Communication Nigeria Publishers, Enugu Olashore J.C.(1996) Money And Banking Analysis And Policy In The Nigeria Context, Macmillan Ltd. London Ojo A.M.(2001) The Element Of Banking In Nigeria, London, Graham,Burn.

[27]. Onwudiegwu L.M. (2001) Excess Liquidity and Unplanned Inventory. Business Times Wed. 4 April 2001

[28]. Okigbo P. (2001) Banking and Financial Analysis And Policy In The Nigeria Context, Macmillan Ltd. London

[29]. Olayinka S.A. (1999) The Elements of Banking In Nigeria, London, Graham,Burn.

[30]. Okoh F. E. (1997), Strategic Financial Development in LDCs, Academy Press Ltd.

[31]. Olade O. (1999), Banking Operation, D.P. Publications Ltd London.

[32]. Pandy I.M. (1991) Financial Management, Vikas Publishing House Ltd. Revised edition, Minna

[33]. Sadiku E. (1993) "Taming the bank Debtors" Daily Times Monday May 16,1993.

[34]. Serven, L. and A. Solimano. (1992). "Private Investment and macro economic adjustment: A survey". The World Bank Research Observer, vol. 7, no. 1 (January).

[35]. Skully, M. (1997). "The South Pacific: Financ, Development and the private sector", International Development Issues no. 48, Australian Agency for International Development, Canberra. 
[36]. Soyode M. Etal (1996) Money and Finance in Nigeria, John Wesley and Sons, New York Shegolar L. (1999) Money Management, University Press Ltd

[37]. Teriba L. (1993) The Financial System, Macmillan Pub. Ltd London Ude M.O. (1996) International Trade and Finance, John Jacobs Classical Publishers Ltd. Enugu

[38]. Uzoaga W. (2006) Money and Banking in Nigeria, Fourth Dimension Publishers Ltd

[39]. Wole Adewunmi (1984), Loan Management in Nigeria Bank University of Wales Press England. 